RESEARCH Note

\title{
Abundance of early life stages of the surf silverside Notocheirus hubbsi (Teleostei, Atheriniformes) in the coastal nearshore of central Chile
}

\author{
Abundancia de estadios tempranos del pejerreicillo Notocheirus hubbsi (Teleostei, \\ Atheriniformes) en las costas de Chile central

\section{Francisca Zavala-Muñoz ${ }^{1}$, Mauricio F. Landaeta ${ }^{1,2,5^{*}}$, Valentina Bernal-Durán ${ }^{1,3}$, Claudia A. Bustos ${ }^{1,2}$ and Brian S. Dyer ${ }^{4}$}

\author{
${ }^{1}$ Laboratorio de Ictioplancton (LABITI), Instituto de Biología, Facultad de Ciencias, Universidad de Valparaíso, Avenida Gran Bretaña \\ 1111, Playa Ancha, Valparaíso, Chile \\ ${ }^{2}$ Centro de Observación Marino para Estudios de Riesgos del Ambiente Costero (COSTA-R), Universidad de Valparaíso, Viña del \\ Mar, Chile \\ ${ }^{3}$ Instituto de Ecología y Biodiversidad (IEB), Casilla 653, Santiago, Chile \\ ${ }^{4}$ Centro de Estudios Generales, Universidad de los Andes, Santiago, Chile \\ ${ }^{5}$ Millennium Nucleus for the Ecology and Conservation of Temperate Mesophotic Reef Ecosystem (NUTME), Las Cruces, Valparaíso, \\ Chile \\ *Corresponding author: mauricio.landaeta@uv.cl
}

\begin{abstract}
The abundance of early stages of the surf silverside Notocheirus hubbsi in nearshore waters of central Chile, collected in samplings set up to assess the lunar cycle during austral spring and summer is reported. A total of 19 specimens were collected with light traps, 16 larvae (7.89-16.20 mm SL) in austral spring and 3 juveniles (30.70-34.60 mm SL) in summer. Capture per unit effort (CPUE) varied from 0.33 to 2.00 ind. light trap $^{-1}$ night $^{-1}$ during the entire study period (September 2015-February 2016, and September 2016-February 2017). N. hubbsi catches recorded maximum abundance during the new moon and no catches during full moon.
\end{abstract}

Key words: Moon cycle, Atheriniformes, light trap, sandy beach

\section{INTRODUCTION}

The surf silversides Notocheirus hubbsi are small, laterally compressed and deep-bodied fish that feature singular morphological traits, such as high-positioned pectoral fins and the presence of odontodes on the dermal bones of their heads and scales (Saeed et al. 1994, Dyer 2000). This species is distributed from Coquimbo, Chile (southeastern Pacific Ocean) and Puerto Deseado, Argentina (south-western Atlantic Ocean), to the southernmost limit of Tierra del Fuego (Dyer \& Chernoff 1996, Carrasco et al. 2017, Díaz-Astudillo et al. 2019). In Chile, N. hubbsi is considered as a rare species because it has been collected only on a few occasions and unexpectedly, in light traps or intertidal pools in southern Chile (Dyer \& Chernoff 1996), and from the surf zone in Argentinean Patagonia (Gosztonyi 1972). No further attempts have been reported to collect them in the surf zone. There are a few reports about the phylogeny and adult morphology for this species (Saeed et al. 1994, Dyer \& Chernoff 1996, Saeed et al. 2006, Bloom et al. 2012). There is no available literature on the early life history stages of this species, and the knowledge of this species' biology is sparse at best, mostly based on the Gosztonyi's works (1972) who collected 22 all female specimens, which was the highest number fished from the surf zone. This author described that this fish feeds primarily on copepods and has a reduced reproductive potential. He also described the eggs as having filaments, but none have ever been found in situ attached to coastal rocky reefs. Hence, there is no clue about where this species spawns nor its development at hatching.

The coastal ichthyoplankton assemblages can vary in composition and abundance, influenced by environmental factors such as the moon cycle, through tidal currents and luminosity variations (Díaz-Astudillo et al. 2017, 2019), therefore, it is expected that the lunar cycle may have an impact on the abundance of larval $N$. hubbsi in temperate waters. In this short communication, the temporal variation in collections of larval and juvenile $N$. hubbsi, in nearshore waters of a bay off central Chile, are described for the first time. 


\section{MATERIALS AND METHODS}

Specimens were collected in the sandy El Quisco Bay $\left(33^{\circ} 24^{\prime} \mathrm{S}, 71^{\circ} 42^{\prime} \mathrm{W}\right)$, central Chile, using light traps (CARE, Ecocean, Montpellier, France), set up weekly on a lunar basis (collected in first quarter, full moon, third quarter, and new moon) between September 2015 and February 2016 ( $n=$ 16), and between September 2016 and February 2017 ( $\mathrm{n}=$ 3). Each Ecocean light trap consists of a buoyant water-tight block containing a $12 \mathrm{~V}$ battery and a $55 \mathrm{~W} 90$ LED light, under which a $2 \mathrm{~m}$ long conical net was attached vertically with a $2 \mathrm{~mm}$ mesh and a narrow funnel in the middle.

Three light traps were deployed on the surface at sampling depths of $\sim 20 \mathrm{~m}$ using a moored buoy, $\sim 300 \mathrm{~m}$ from shore, and $\sim 500 \mathrm{~m}$ apart from each other. The codends were removed at the end of each evening's catch (after $\sim 8-9$ hours) and treated with benzocaine (BZ-20, Veterquímica S.A., Chile) before preservation in $96 \%$ ethanol. Abundance was standardized to CPUE (capture per unit of effort, specimens per light trap ${ }^{-1}$ night $\left.^{-1}\right)$. During these samplings, oceanographic, meteorological and satellite data were also registered. A detailed explanation of the sampling design is given by Díaz-Astudillo et al. (2019).

In the laboratory, larvae were sorted and identified according to the descriptions from Dyer (2000). All individuals were dissected for stomach content analysis, but only a few presented highly digested remains that were of no use to conduct further analyses. The largest collected individual (34.60 mm SL) was illustrated (Fig. 1).

\section{RESULTS AND DISCUSSION}

A total of 19 specimens were collected in the light traps: 16 larvae (7.89-16.2 mm SL; collected during OctoberDecember 2015) and 3 juveniles (30.70-34.60 mm SL; captured during January 2016, December 2016 and February 2017), respectively (Fig. 1).

Two specimens were severely damaged by crustacean megalopae after light-trap recovery and were not included in further analyses.

CPUE of early stages of $N$. hubbsi varied from $0.33 \pm$ 0.57 (mean \pm SD) to $2 \pm 1.73$ ind. light trap ${ }^{-1}$ night $^{-1}$, varying from 0 to 4 ind. light trap ${ }^{-1}$ night $^{-1}$. Larvae were collected between October 20th and December 10th of 2015 (Fig. 2) and had the highest CPUE during the dark phase of the lunar cycle (new moon) (Fig. 3). No larvae were collected during the spring (September to December) of 2016. Only a few juveniles were collected, between January 19th and February 29th 2016. These catches occurred during new moon and first quarter moon (Figs. 2 and 3). The collection of $N$. hubbsi larvae and juveniles could not be attributed to any of the meteorological or oceanographic conditions registered during the samplings (see Díaz-Astudillo et al. 2019 for a complete description of the environmental conditions).

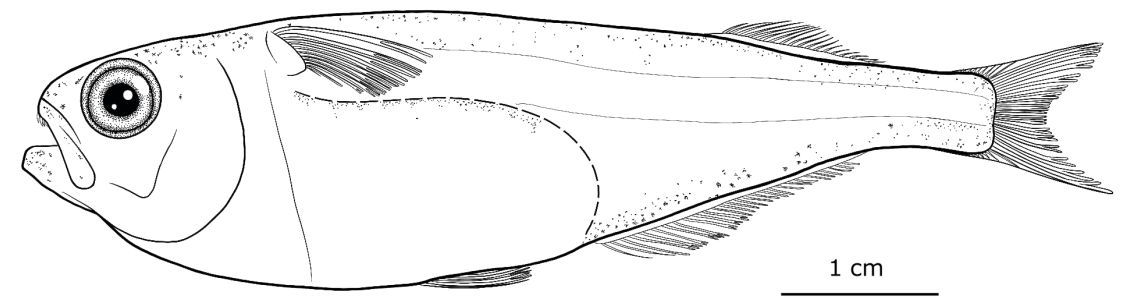

Figure 1. Specimen of surf silverside Notocheirus hubbsi. Drawing by Francisca Zavala-Muñoz / Ejemplar de pejerreicillo Notocheirus hubbsi. Dibujo de Francisca Zavala-Muñoz 


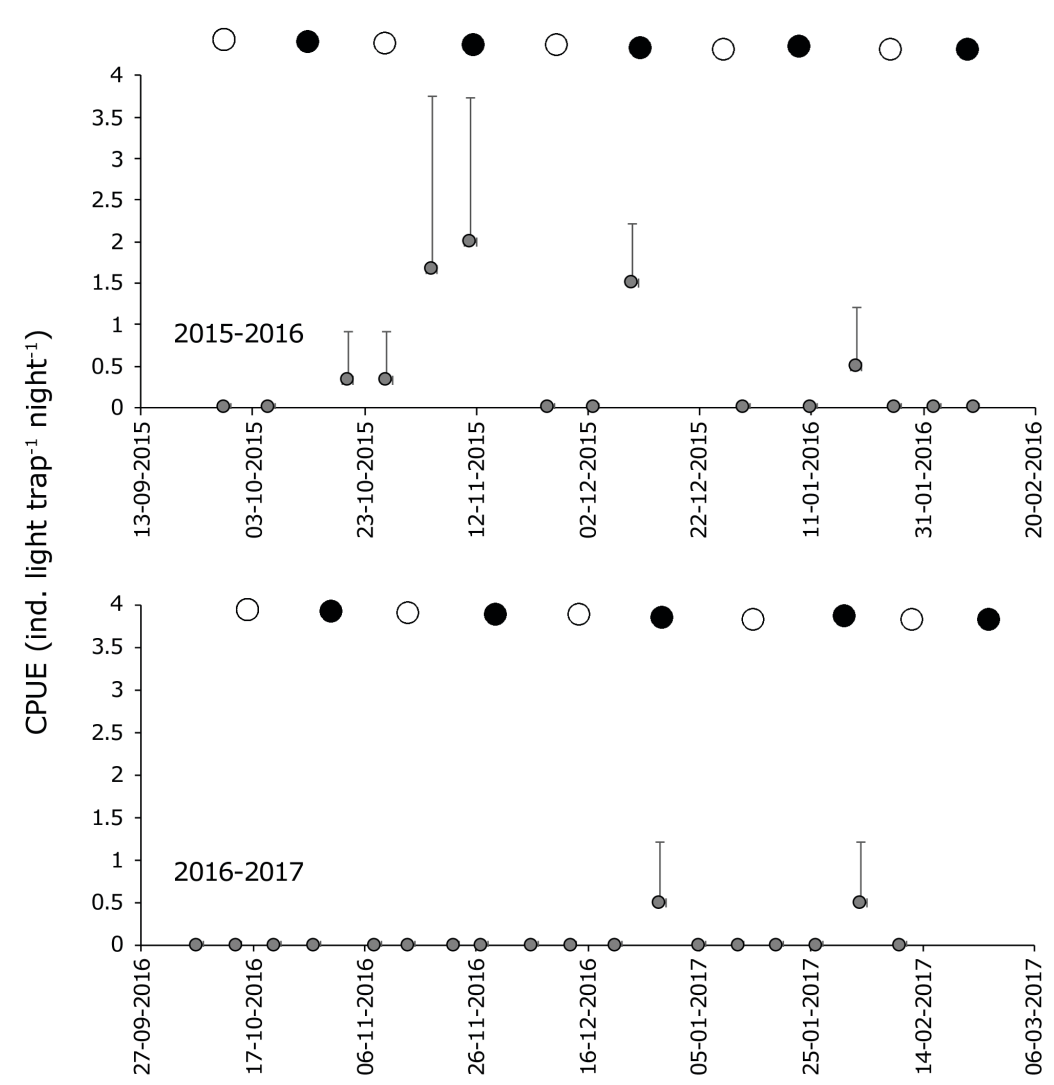

Figure 2. Temporal variation of the Capture Per Unit of Effort (CPUE, mean \pm SD) of the surf silverside, during austral Spring and Summer 2015-2016 and 2016-2017. White and black circles represent full and new moon, respectively / Variación temporal de la Captura Por Unidad de Esfuerzo (CPUE, media \pm DE) del pejerreicillo, durante primavera y verano austral de 2015-2016 y 2016-2017. Los círculos blanco y negro representan a la luna llena y nueva, respectivamente

The early stages of $N$. hubbsi were collected more frequently in mid-spring and during new moon, when there was less luminosity and the signal of the light trap could have been perceived more clearly. Clark (1937) described this species based on two adult specimens "taken around light" during February in Valparaiso harbor. Therefore, this species seems to show a positive phototaxis throughout its life history.

Larvae of $N$. hubbsi are rarely obtained in plankton samples collected in nearshore waters $(\sim 500-300 \mathrm{~m}$ from coast) off central Chile (Landaeta et al. 2009, 2015). It is plausible that their early life stages may be retained or aggregated in the surf zone of sandy beaches, where Gosztonyi successfully collected the individuals he described (Gosztonyi 1972). Due to the large physical disturbance generated by breaking waves, the surf zone creates a suitable environment for fish larvae, sheltered from predators and with an abundance of food resources (Pattrick \& Strydom 2014). Reportedly, N. hubbsi individuals have a series of morphological features that possibly reflect their adaptation to this type of environment, such as a

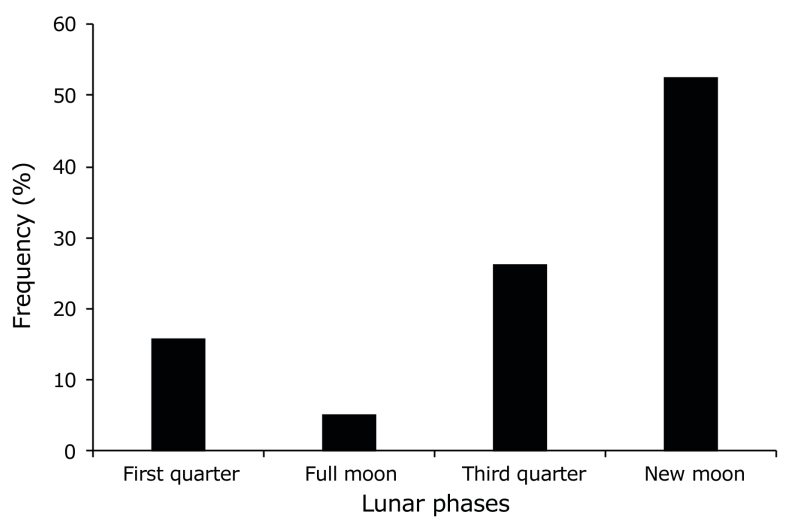

Figure 3. Frequency (\%) of CPUE of the surf silverside on a lunar scale / Frecuencia (\%) de la CPUE del pejerreicillo en una escala lunar

tear-drop body shape, high positioning of pectoral fins and a ventral abdominal keel (Saeed et al. 1994). These bodyshape features were present even in the smallest collected individual (B Dyer, pers. obs.). Nonetheless, there is a lack of information about the exploitation of that habitat by $N$. hubbsi and other marine fish species from sandy beaches. 


\section{ACKNowledgments}

This research was funded by Comisión Nacional de Investigación Científica y Tecnológica (CONICYT, Chile) by Project FONDECYT 1150296, to MFL.

\section{LITERATURE CITED}

Bloom DD, PJ Unmack, AE Gosztonyi, ER Piller \& NR Lovejoy. 2012. It's a family matter: Molecular phylogenetics of Atheriniformes and the polyphyly of the surf silversides (Family: Notocheiridae). Molecular Phylogenetics and Evolution 62: 1025-1030.

Carrasco SA, L Vandecasteele, MM Rivadeneira, M Fernández \& A Pérez-Matus. 2017. Spatial and shortterm variability of larval, post-larval and macrobenthic assemblages associated with subtidal kelp forest ecosystems in Central Chile. Marine Biology Research 13: 1041-1058.

Clark HW. 1937. New fishes from the Templeton Crocker Expedition of 1934-35. Copeia 1937: 88-91.

Díaz-Astudillo M, MI Castillo, MA Cáceres, G Plaza \& MF Landaeta. 2017. Oceanographic and lunar forcing affects nearshore larval fish assemblages from temperate rocky reefs. Marine Biology Research 13: 1015-1026.

Díaz-Astudillo M, MF Landaeta, V Bernal-Durán, MI Castillo, M Alvarado-Niño \& D Alarcón. 2019. The influence of regional and local oceanography in early stages of marine fishes from temperate rocky reefs. Marine Biology 166: 42. <https://doi.org/10.1007/s00227-0193489-1>

Dyer BS. 2000. Revisión sistemática de los pejerreyes de Chile (Teleostei: Atheriniformes). Estudios Oceanológicos 19: 99-127.
Dyer BS \& B Chernoff. 1996. Phylogenetic relationships among atheriniform fishes (Teleostei: Atherinomorpha. Zoological Journal of the Linnean Society 117: 1-69.

Gosztonyi AE. 1972. Notocheirus hubbsi Clark 1937 (Pisces, Isonidae), adición a la fauna Argentina de peces marinos. Physis 31(83): 579-583.

Landaeta MF, K Schrebler, CA Bustos, J Letelier \& F Balbontín. 2009. Temporal fluctuations of nearshore ichthyoplankton off Valparaíso, central Chile, during the ENSO cycle 1997-2000. Revista de Biología Marina y Oceanografía 44: 571-582.

Landaeta MF, F Zavala-Muñoz, P Palacios-Fuentes, CA Bustos, M Alvarado-Niño, J Letelier, MA Cáceres \& G Muñoz. 2015. Spatial and temporal variations of coastal fish larvae, ectoparasites and oceanographic conditions off central Chile. Revista de Biología Marina y Oceanografía 50: 563-574.

Pattrick P \& NA Strydom. 2014. The effects of exposure in sandy beach surf zones on larval fishes. Journal of Fish Biology 84: 1354-1376.

Saeed B, W Ivantsoff \& LELM Crowley. 1994. Systematic relationships of the atheriniform families within Division I of the series Atherinomorpha (Acanthopterygii) with relevant historical perspectives. Journal of Ichthyology 34: 27-72.

Saeed B, W Ivantsoff \& AAarn. 2006. Descriptive anatomy of Iso rhothophilus (Ogilby), with a phylogenetic analysis of Iso and a redefinition of Isonidae (Atheriniformes). Aqua, Journal of Ichthyology and Aquatic Biology 11: 25-43. 